RESEARCH ARTICLE

\title{
Biometric similarity Test of The Population of T. (Zaria) bantamensis tjicumpaensis with T. (Zaria) javana as a Form of Phylogeny And Evolutionary Proximity
}

\author{
Hita Pandita ${ }^{1 *}$, Ani Apriani ${ }^{1}$ \\ ${ }^{1}$ Department of Geological Engineering, Institut Teknologi Nasional, Yogyakarta, Indonesia.
}

* Corresponding author : hita@sttnas.ac.id

Tel+6285800081053/Fax:+62 274487249

Received: Apr 25, 2021; Accepted: Sept 22, 2021

DOI: 10.25299/jgeet.2021.6.3.6780

\begin{abstract}
Biometric aspects in the Turritellidae family need to be studied as an important identification parameter. Zaria, which is one of the sub genera in the Turritellidae family, deserves to be tested in order to determine the feasibility of the biometric aspect as an identification parameter. This paper aims to provide an overview of the benefits of the biometric aspect as an identification parameter. The method used to re-identify the biometric and morphological aspects of the T. (Zaria) bantamensis tjicumpaensis population with T. (Zaria) javana. The results of the identification were carried out by a T-Test on the biometric aspect to see the similarity of the biometric aspects of the two populations. Based on the results of the TTest on the parameters of the Wsut: Wang and Wsut: L ratio, it shows that the two Zaria species are the same. Meanwhile, from the morphological aspect, there is a slight difference in the early growth peripherals.
\end{abstract}

Keywords: Biometrical, Zaria, Turritellidae, T-Test, morphological

\section{Introduction}

Biometry is one method of identification of fossils, in the form of measurements of certain parts of the body. The biometric aspect as an identification parameter in fossils has not been widely used as a key parameter in determining species (Imbrie, 1956; Pandita et al., 2013). This is because a sufficient amount of sample data is needed to be able to see the pattern of the biometrics. Therefore, research on the role of biometry as an important parameter in fossil identification needs to be carried out continuously.

Zaria, which is a group of fossils from the Turritellidae family, is a sub-genera of Turritella which is interesting to study from its biometric aspect. This is due to the fact that numbers of species of Zaria found on Java Island are morphologically similar, but are separated into different species (Pandita, 2014).

This condition is also shown between T. (Zaria) javana from the location of the Cijarian-Sukabumi river and T. (Zaria) bantamensis from the Cimadur-Bayah area. The two populations are almost similar morphologically. Seeing this problem, it is necessary to study the biometric aspects of the two populations between $T$. (Zaria) javana and T. (Zaria) bantamensis tjikumpaensis.

\section{Objectives}

The purpose of this paper is to provide a morphological and biometric description of the population of Zaria bantamensis tjikumapensis and Zaria javana. The aim is to find out how the biometric aspects provide clarity of the speciiation of the two populations and the opportunities for their phylogeny of closeness. This study is also aimed at reintroducing the biometric parameters used by Pandita et al., (2013).

\section{Materials}

The research sample is a collection stored in the Bandung Geology Museum and the ITNY Paleontology Laboratory with a total of 52 samples. The samples came from two locations in West Java Province and Banten Province. The sample $T$. (Zaria) bantamensis tjicumpaiensis came from the Bayah (BYH) location with coordinates $06^{\circ} 54^{\prime} 09,2^{\prime \prime} \mathrm{S}$ and $106^{\circ} 14^{\prime}$ 48,5 "E. While the T. (Zaria) javana sample came from the Cijarian River with location coordinates $06^{\circ} 59^{\prime} 31.3$ "S and $106^{\mathrm{O}} 38^{\prime}$ 01.6" E (Figure 1).

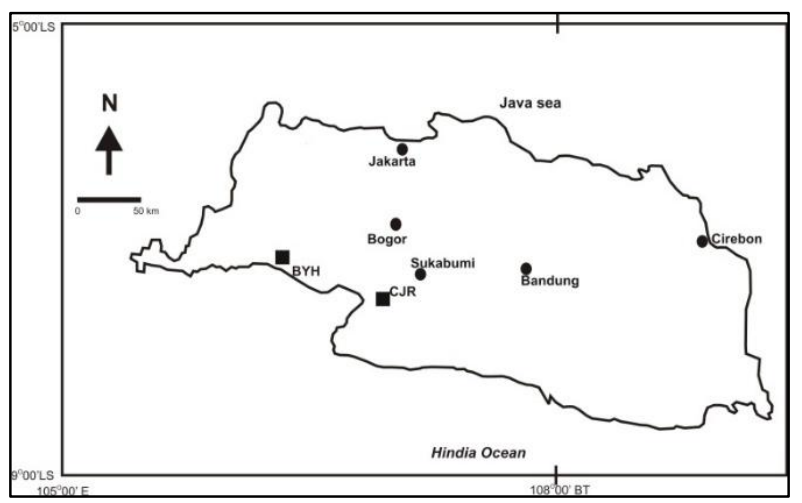

Fig 1. The sampling locations were from the Bayah (BYH) area in Banten Province and the Cijarian river (CJR) in the Sukabumi area of West Java Province

\section{Methods}

The method in this research is to re-identify the morphological and biometric aspects of the two sample populations stored in the ITNY Paleontology Laboratory. The 
sample coded CJR03 is a population of Zaria javana, and BYH01 is a population of Zaria bantamensis tjikumpaensis After the identification was carried out, statistical analysis was carried out using linear regression and T-Test on biometric parameters.

Identification of morphological aspects is using parameters from (Kotaka, 1959); (Marwick, 1957); Merriam, 1941). These parameters include: 1) the number of main spiral ribs, 2) peripheral patterns, 3) room shape, 4) sutures, 5) keel characters and 6) apertura (Figure 2).

The biometric aspect uses the parameters proposed by Pandita et al., (2013). These parameters include: 1) L (shell length), 2) Wsut (last chamber suture diameter), 3 Wang (last chamber diameter) (Figure 2).

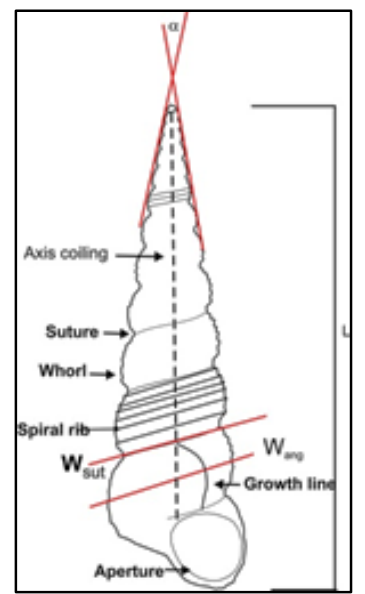

Fig 2. Identification Parameters of Zaria

The statistical test conducted is the similarity test using two methods. The first method uses linear regression. The second method uses the Independent T-Test, while the formula used (Hasan, 2004) is as follows:

$$
t=\frac{x_{1}-x_{2}}{s \sqrt{\frac{1}{n_{1}}+\frac{1}{n_{2}}}}
$$

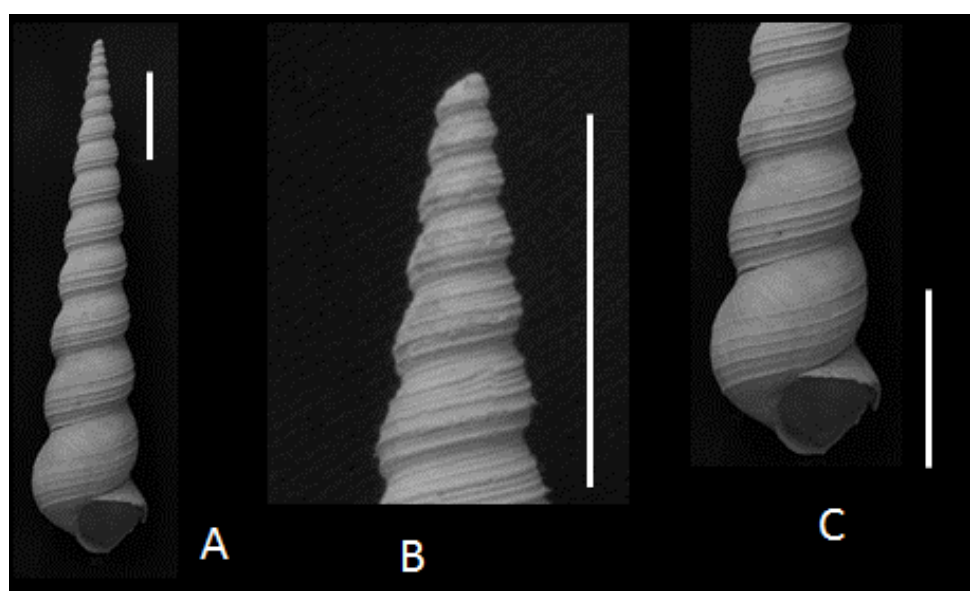

Fig 3. Turritella (Zaria) bantamensis tjicumpaiensis: A) complete shell B) Early Teleconch, C) Adult Teleconch, Scale bar = $1 \mathrm{~cm}$.

\subsection{Morphologic Descriptive}

The shell that appears is predominantly small, although some are larger than $60 \mathrm{~mm}$. At the beginning of its growth, the main spiral ribs that appear are 4 , with a multicostate structure. The shape of the suture is initially channelized and then changes
Where: $\mathrm{t}=$ value of acceptance if $-\mathrm{t}_{(1-1 / 2 \alpha)}<\mathrm{t}<\mathrm{t}(1-1 / 2 \alpha)$

$\mathrm{x} 1 \& \mathrm{x} 2=$ mean values

$\mathrm{n} 1 \& \mathrm{n} 2=$ number of population

$\mathrm{S} \quad=$ is the average standard deviation

The formula for the average standard deviation of the two populations:

$$
S^{2}=\frac{\left(n_{1}-1\right) S_{1}^{2}+\left(n_{2}-1\right) S_{2}^{2}}{n_{1}+n_{2}-2}
$$

Where: S1 \& S2 = standard deviation value of each tested population.

\section{Systematic Description}

The taxonomic systematics used in the preparation of the classification refers to Leloux and Wesselingh, (2009).

Class : Gastropoda Cuvier, 1797

Sub class : Prosobranchia Milne-Edwards, 1848

Order : Mesogastropoda Thiele, 1925

Super Family : Cerithiacea Fleming, 1822

Family : Turritellidae Loven, 1847

Genera : Turritella Lamarck, 1799

Sub Genera: Zaria Grey 1847

Species: Turritella (Zaria) bantamensis tjicumpaiensis Martin, 1905

Figure: 3

Turritella tjicumpaiensis — (Martin, 1905): 232, pl. 35, figs 549-550

Turritella tjicumpaiensis Martin — Van der Vlerk, 1931: 254

Turritella (Turritella) bantamensis tjicumpaiensis Martin (Shuto, 1974): 144

Turritella (Turritella) bantamensis tjicumpaiensis Martin (Shuto, 1978): 103

Turritella (Turritella) bantamensis tjicumpaiensis Martin (Skwarko, S.K.; Sufiati, 1994): f9

Material: Paratype. Shell preservation is not complete, protoconch is loose. The number of preserve whorl about 8 to 9 whorls. Specimens are stored in the ITNY Paleontology Laboratory sample code BYH01 is 11 specimens, and at the Geology Museum Bandung the sample code is B-29 as 6 specimens and $14 \mathrm{C}$ as 6 specimens. 
Table 1. Biometrical aspect of T. (Zaria) bantamensis tjicumpaiensi

\begin{tabular}{|c|c|c|c|c|c|c|c|c|}
\hline No.Spec & $\mathrm{L}_{(\mathrm{mm})}$ & $\mathrm{W}_{\text {ang }}$ & $\mathrm{W}_{\text {sut }}$ & $\alpha\left({ }^{\mathrm{O}}\right)$ & $\mathrm{n}$ Whorl & $\mathrm{W}_{\text {ang }}: \mathrm{L}$ & $\mathrm{W}_{\text {sut }}: \mathrm{L}$ & $\mathrm{W}_{\text {sut }}: \mathrm{W}_{\text {ang }}$ \\
\hline BYH01-1 & 121.30 & 26.80 & 19.90 & 10.00 & 15.00 & 0.2209 & 0.1641 & 0.7425 \\
\hline ВYH01-2 & 57.50 & 16.30 & 11.60 & 13.00 & 14.00 & 0.2835 & 0.2017 & 0.7117 \\
\hline BYH01-3 & 36.60 & 11.35 & 8.10 & 13.00 & 11.00 & 0.3101 & 0.2213 & 0.7137 \\
\hline BYH01B-1 & 48.40 & 13.10 & 9.65 & 10.00 & 8.00 & 0.2707 & 0.1994 & 0.7366 \\
\hline BYH01B-2 & 45.20 & 12.80 & 9.50 & 10.00 & 8.00 & 0.2832 & 0.2102 & 0.7422 \\
\hline ВYH01B-3 & 45.10 & 11.40 & 8.60 & 8.00 & 9.00 & 0.2528 & 0.1907 & 0.7544 \\
\hline BYH01B-4 & 36.65 & 10.90 & 8.20 & 9.50 & 7.50 & 0.2974 & 0.2237 & 0.7523 \\
\hline BYH01B-5 & 33.80 & 10.70 & 8.20 & 9.50 & 7.00 & 0.3166 & 0.2426 & 0.7664 \\
\hline ВYH01B-6 & 37.45 & 10.65 & 8.30 & 10.00 & 8.00 & 0.2844 & 0.2216 & 0.7793 \\
\hline BYH01B-7 & 40.35 & 10.60 & 7.70 & 9.00 & 9.00 & 0.2627 & 0.1908 & 0.7264 \\
\hline BYH01B-8 & 43.10 & 13.00 & 9.80 & 8.50 & 9.00 & 0.3016 & 0.2274 & 0.7538 \\
\hline B29-1 & 50.60 & 14.90 & 10.00 & 8.50 & 13.00 & 0.2945 & 0.1976 & 0.6711 \\
\hline B29-2 & 49.90 & 13.30 & 9.40 & 10.00 & 12.00 & 0.2665 & 0.1884 & 0.7068 \\
\hline B29-3 & 53.00 & 15.60 & 11.70 & 9.50 & 11.00 & 0.2943 & 0.2208 & 0.7500 \\
\hline B29-4 & 93.00 & 22.00 & 15.50 & 8.00 & 17.00 & 0.2366 & 0.1667 & 0.7045 \\
\hline B29-5 & 90.90 & 21.30 & 16.00 & 11.00 & 14.00 & 0.2343 & 0.1760 & 0.7512 \\
\hline В29-6 & 29.20 & 8.80 & 5.30 & 9.00 & 10.00 & 0.3014 & 0.1815 & 0.6023 \\
\hline $14 C 4-1$ & 63.25 & 17.70 & 13.20 & 10.00 & 12.00 & 0.2798 & 0.2087 & 0.7458 \\
\hline $14 C 4-2$ & 60.45 & 16.00 & 11.65 & 9.50 & 13.00 & 0.2647 & 0.1927 & 0.7281 \\
\hline $14 C 4-3$ & 62.70 & 17.10 & 11.65 & 10.00 & 12.00 & 0.2727 & 0.1858 & 0.6813 \\
\hline $14 C 4-4$ & 71.90 & 17.85 & 12.60 & 10.00 & 14.00 & 0.2483 & 0.1752 & 0.7059 \\
\hline $14 C 4-5$ & 55.80 & 14.50 & 10.50 & 9.50 & 13.00 & 0.2599 & 0.1882 & 0.7241 \\
\hline $14 C 4-6$ & 58.00 & 14.80 & 10.60 & 9.00 & 14.50 & 0.2552 & 0.1828 & 0.7162 \\
\hline Mean & 55.83 & 14.85 & 10.77 & 9.76 & & 0.2736 & 0.1982 & 0.7246 \\
\hline $\mathrm{S}$ & 21.65 & 4.29 & 3.18 & 1.25 & & 0.0253 & 0.0208 & 0.0375 \\
\hline
\end{tabular}

\section{Species: Turritella (Zaria) javana Martin, 1883}

Figure 4

Turritella javana Martin, 1883: 233, pl. 11, fig. 27. Turritella javana Martin -(Martin, 1884): 171. Turritella javana Martin - (Martin, 1905): 227.
Zaria javana (Martin) - (Shuto, 1974): 140

Zaria javana (Martin) - (Skwarko, S.K.; Sufiati, 1994): f15.

Material : Lectotype. Shell preservation is not complete, protoconch is loose. The number of preserve whorl about 9 to 11 whorls. Total specimen is 29, stored in Laboratory of Paleontology ITNY. Code number CJR03.

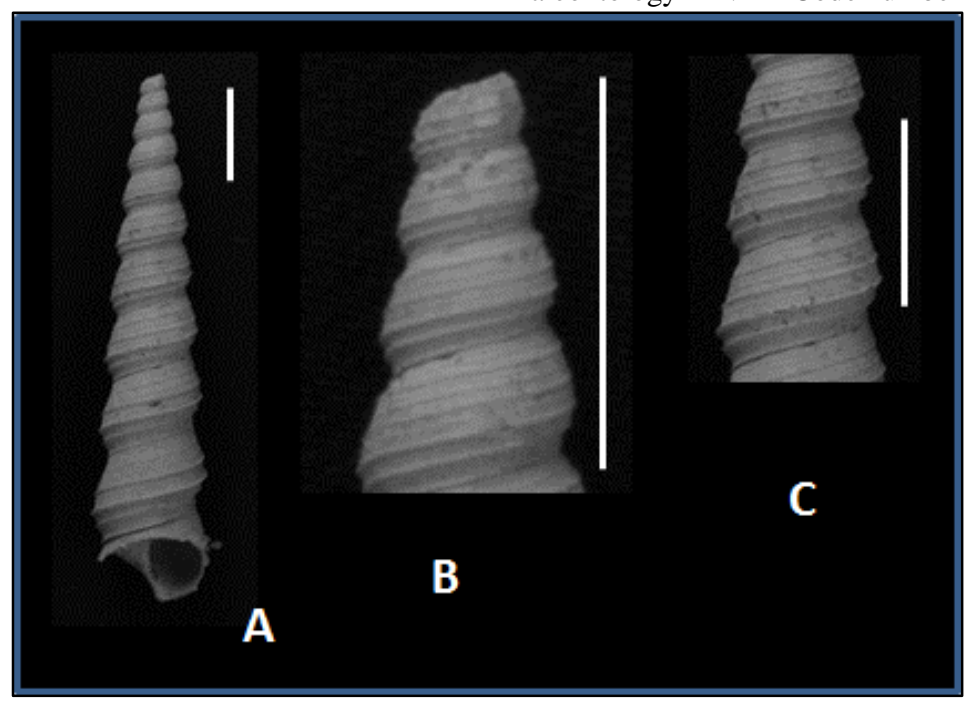

Fig 4. Turritella (Zaria) javana: A) complete shell B) Early Teleconch, C) Adult Teleconch, Scale bar $=1 \mathrm{~cm}$.

\subsection{Morphologic Descriptive}

Shell including small to medium sized. In the early rounds made up four primary spirals appears at the beginning teloconch. Whorl shape tends tricostate formed by spiral into 1 , 2 and 3 are sorted from the anterior, with a spiral rib to 2 expressed slightly stronger than the other two. A fine spiral located under the posterior sutures as a spiral 4 . Sutures at the beginning teleconch shaped channelled.Start whorl to 7 there is a change of sutures and pheriperal form. Forms bicarinate appear in the center of the whorl that is formed by a spiral rib of the anterior second and third. Relative changes to subcarinate sutures. Lateral growth line strongly curved with a single sinus, and basal sinuses also appeared at the bottom. Aperture somewhat elliptical until rounded. 
Table 2. Biometrical aspect of T. (Zaria) javana

\begin{tabular}{|c|c|c|c|c|c|c|c|c|}
\hline No.Spec & $\mathrm{L}_{(\mathrm{mm})}$ & $\mathrm{W}_{\text {ang }}$ & $\mathrm{W}_{\text {sut }}$ & $\alpha\left(^{(}\right)$ & n Whorl & $\mathrm{W}_{\text {ang }}: \mathrm{L}$ & $\mathrm{W}_{\text {sut }}: \mathrm{L}$ & $\mathrm{W}_{\text {sut }}: \mathrm{W}_{\text {ang }}$ \\
\hline CJR3A-1 & 51.90 & 14.75 & 10.45 & 15.00 & 12.00 & 0.28420 & 0.20135 & 0.70847 \\
\hline CJR3A-2 & 61.20 & 14.65 & 10.35 & 13.00 & 13.00 & 0.23938 & 0.16912 & 0.70648 \\
\hline CJR3A-3 & 53.80 & 14.90 & 10.25 & 13.50 & 11.50 & 0.27695 & 0.19052 & 0.68792 \\
\hline CJR3A-4 & 57.60 & 15.00 & 10.85 & 13.00 & 12.50 & 0.26042 & 0.18837 & 0.72333 \\
\hline CJR3A-5 & 56.30 & 16.35 & 11.15 & 13.00 & 12.00 & 0.29041 & 0.19805 & 0.68196 \\
\hline CJR3A-6 & 52.50 & 13.70 & 9.70 & 14.50 & 11.50 & 0.26095 & 0.18476 & 0.70803 \\
\hline CJR3A-7 & 45.30 & 13.30 & 8.95 & 13.50 & 11.50 & 0.29360 & 0.19757 & 0.67293 \\
\hline CJR3A-8 & 54.20 & 14.65 & 10.00 & 14.00 & 12.50 & 0.27030 & 0.18450 & 0.68259 \\
\hline CJR3A-9 & 53.40 & 13.40 & 9.40 & 13.50 & 12.00 & 0.25094 & 0.17603 & 0.70149 \\
\hline CJR3A-10 & 43.40 & 12.85 & 9.10 & 14.50 & 11.50 & 0.29608 & 0.20968 & 0.70817 \\
\hline CJR3A-11 & 46.40 & 12.95 & 9.30 & 14.50 & 12.00 & 0.27909 & 0.20043 & 0.71815 \\
\hline CJR3A-12 & 40.25 & 11.15 & 8.45 & 13.00 & 10.00 & 0.27702 & 0.20994 & 0.75785 \\
\hline CJR3B-1 & 53.60 & 15.00 & 10.70 & 12.50 & 11.00 & 0.27985 & 0.19963 & 0.71333 \\
\hline CJR3B-2 & 59.90 & 15.50 & 11.30 & 13.50 & 11.50 & 0.25876 & 0.18865 & 0.72903 \\
\hline CJR3B-3 & 42.10 & 13.60 & 9.60 & 13.50 & 11.00 & 0.32304 & 0.22803 & 0.70588 \\
\hline CJR3B-4 & 53.45 & 13.55 & 9.50 & 14.00 & 11.00 & 0.25351 & 0.17774 & 0.70111 \\
\hline CJR3B-5 & 54.40 & 15.10 & 11.10 & 13.00 & 10.80 & 0.27757 & 0.20404 & 0.73510 \\
\hline CJR3B-6 & 48.00 & 14.40 & 9.85 & 13.00 & 11.00 & 0.30000 & 0.20521 & 0.68403 \\
\hline CJR3B-7 & 54.85 & 15.25 & 10.85 & 13.00 & 10.80 & 0.27803 & 0.19781 & 0.71148 \\
\hline CJR3B-8 & 50.80 & 13.50 & 10.00 & 13.50 & 11.00 & 0.26575 & 0.19685 & 0.74074 \\
\hline CJR3B-9 & 55.75 & 15.45 & 11.70 & 13.00 & 10.80 & 0.27713 & 0.20987 & 0.75728 \\
\hline CJR3B-10 & 53.70 & 15.70 & 11.80 & 14.50 & 11.00 & 0.29236 & 0.21974 & 0.75159 \\
\hline CJR3B-11 & 65.00 & 15.60 & 11.00 & 12.50 & 12.50 & 0.24000 & 0.16923 & 0.70513 \\
\hline CJR3B-12 & 43.00 & 12.10 & 8.70 & 13.00 & 11.00 & 0.28140 & 0.20233 & 0.71901 \\
\hline CJR3B-13 & 49.30 & 15.30 & 11.10 & 13.50 & 10.00 & 0.31034 & 0.22515 & 0.72549 \\
\hline CJR3B-14 & 50.00 & 15.60 & 11.30 & 13.50 & 11.00 & 0.31200 & 0.22600 & 0.72436 \\
\hline CJR3B-15 & 52.70 & 15.50 & 10.80 & 13.00 & 12.00 & 0.29412 & 0.20493 & 0.69677 \\
\hline CJR3B-16 & 49.40 & 15.20 & 10.70 & 13.00 & 11.00 & 0.30769 & 0.21660 & 0.70395 \\
\hline CJR3B-17 & 46.70 & 13.65 & 9.60 & 14.00 & 10.00 & 0.29229 & 0.20557 & 0.70330 \\
\hline Mean & 51.69 & 14.40 & 10.26 & 13.48 & & 0.28011 & 0.19958 & 0.71258 \\
\hline$S$ & 6.24 & 1.36 & 0.82 & 0.72 & & 0.02102 & 0.01578 & 0.02182 \\
\hline
\end{tabular}

\section{Result}

Phenotypically, the two populations have almost the same morphological physical characteristics, there are only differences in the peripheral pattern in early teleconch, where $T$. (Zaria). javana has a tricostate pattern (Figure 4B), while $T$. (Zaria). bantamensis has multicostate (Figure 3B). Seeing this, it is necessary to test the similarity on biometry whether the two populations are indeed different or the same. Biometric data has been presented in tables 1 and 2 .

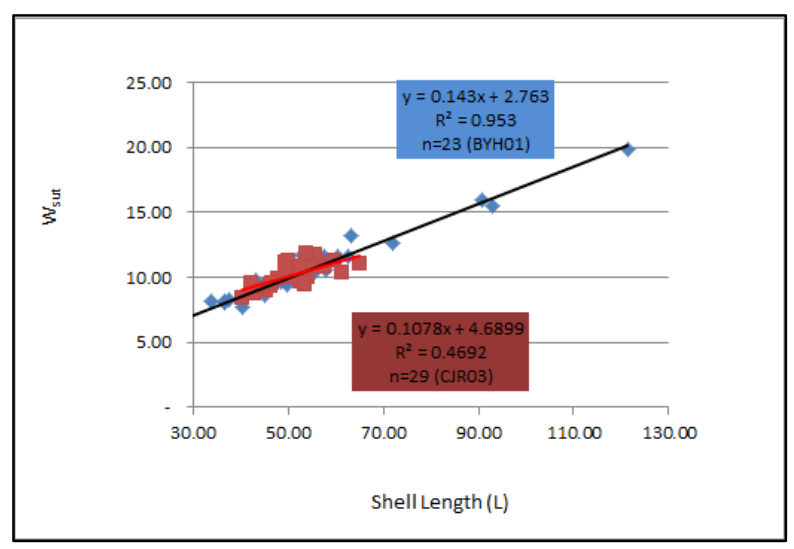

Fig 5. Linear regression pattern of the parameters Wsut: $\mathrm{L}$ ratio between Z. javana (CJR03) with Z. Bantamensis tjicumpaiensis (BYH01).

The first study conducted a linear regression pattern analysis to see if there was no relationship between the two species. The Wsut: L and Wsut: Wang ratios show that the two species have parallel and coincided linear lines (Figures 5 and
6). Based on this, the two populations have the same growth pattern.

The second study was analyzed using a two-way difference test known as the T-Test. Data processing using excel program. The acceptance level used $(\alpha=0.05)$, is a number commonly used in the T-Test. So that the acceptance limit for the total number of the two populations of 52 samples is $-2.008<t_{0}$ $<2.008$ is obtained from the $t$ distribution table (Hasan, 2004). Based on the results of the T-Test test, it shows that the two parameters produce a value of $t_{0}=-0.27736$ for the Wsut: $\mathrm{L}$ ratio and $t_{0}=1.406124$ for the Wsut:Wang ratio (Table 3 ). The two values fall into the acceptance range, so that the two populations can be considered to have the same pattern.

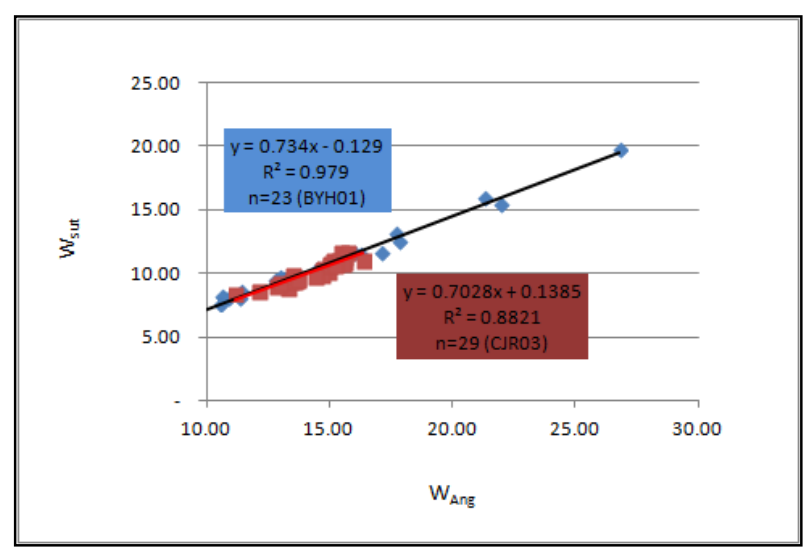

Fig 6. Linear regression pattern of the parameters the Wsut: Wang ratio between Z. javana (CJR03) with Z. bantemensis tjikumpaensis (BYH01). 
Table 3. T-Test results on two parameters of the ratio of Wsut: L and Wsut: Wang from two populations of species Z. javana (CJR03) with Z. bantemensis tjikumpaensis (BYH01).

\begin{tabular}{|c|c|c|c|c|c|c|c|c|c|}
\hline \multirow{2}{*}{$\begin{array}{l}\text { Samples } \\
\text { Number }\end{array}$} & \multirow{2}{*}{ Spesies } & \multirow{2}{*}{$\begin{array}{c}\text { Sample } \\
\text { s Size } \\
\text { (n) }\end{array}$} & \multirow{2}{*}{$\begin{array}{c}\mathrm{t}_{0} \\
\alpha=0.05\end{array}$} & \multirow{2}{*}{$\mathrm{W}_{\text {sut }}: \mathrm{L}$} & \multirow{2}{*}{$\mathrm{W}_{\text {sut }}: \mathrm{W}_{\text {ang }}$} & \multicolumn{2}{|c|}{ T-Test ( $\left.\mathrm{W}_{\text {sut }}: \mathrm{L}\right)$} & \multicolumn{2}{|c|}{ T-Test ( $\left.\mathrm{W}_{\text {sut }}: \mathrm{W}_{\text {ang }}\right)$} \\
\hline & & & & & & $\mathrm{s}$ & $\mathrm{t}$ & $\mathrm{s}$ & $\mathrm{t}$ \\
\hline BOJ03 & Z. bantamensis & 28 & \multirow{2}{*}{2.004} & 0.1700 & 0.7303 & \multirow{2}{*}{0.0151} & \multirow[t]{2}{*}{-7.3660} & 0.0250 & \multirow[t]{2}{*}{2.6722} \\
\hline CJR03 & Z. javana & 29 & & 0.1996 & 0.7126 & & & & \\
\hline
\end{tabular}

\section{Discusion}

Seeing the test results of both the linear regression pattern and the T-Test test for both populations can be said to have the same character. The separation of the two as different species needs to be reviewed, considering that from a biometric point of view they both have similarities.

Almost all morphological parameters of the two populations are also the same, with a slight difference in the peripheral pattern at the early teleconch. However, the initial growth pattern by Kotaka, (1959), Marwick, (1957) is one of the factors that differentiate species, so it is difficult to propose that both species are the same. However, by looking at the proximity of the biometric aspects and spiral rib patterns in adult teleconch, the two have a close phylogeny relationship.

In terms of geology, these two populations or species come from two different locations. T. (Zaria) javana comes from the Nyalindung Formation which is thought to have formed in the Upper Miocene (Pandita et al., 2013). Meanwhile, Z. bantamensis comes from the Cimanceuri Formation (BYH01) where the formation is estimated to be in the Early Pliocene age (Pandita, 2014).

Combining with the age of appearance of the two species, of which T. (Zaria) javana is older, namely the Upper Miocene, it is certain that $T$. (Zaria) bantamensis tjicumpaiensis evolved from $T$. (Z) javana.

\section{Conclusion}

Both populations of the sub-genus Zaria show the same biometric characteristics. Meanwhile, in the morphological aspect, there is a small difference in early teleconch. However, because the early teleconch by Kotaka (1959) was the determining parameter of the species, the two populations could not be categorized as the same species. This condition implies the need for a ranking test on the identification parameters of Turritella (Zaria) as well.

\section{Acknowledgment}

Gratitude is conveyed to ITNY for providing research funding in the 2020 budget year, through a fundamental research program.

\section{References}

Hasan, 2004. Analisis Data Penelitian Dengan Statistik. Bumi Aksara, Yogyakarta.

Imbrie, J., 1956. Biometrical Methods in The Study of Invertebrate Fossils, in: Bulletin of The American Museum of Natural History. American Museum of Natural History, New York, pp. 214-251.
Kotaka, T., 1959. The Cenozoic Turritellidae of Japan. Sci. Rep. 31, 1-135.

Leloux, J; Wesselingh, F.P., 2009. Types of Cenozoic Mollusca from Java in the Martin Collection of Naturalis. NMNH, 765.

Martin, K., 1905. Modulus - Delphinula, in: Martin, K. (Ed.), Die Fossilien von Java Auf Grund Einer Sammlung von Dr. R. D. M. Verbeek Und von Anderen. I. Band. Gasteropoda. Mit Einem Anhange Über: Die Foraminiferen Führenden Gesteine. Sammlungen des geologischen Reichs-Museums in Leiden, Leiden, pp. 221-285.

Martin, K., 1884. Systematischer Theil: Mollusca. I. Glossophora. A. Gasteropoda. In: Martin, K. 1883-1887. Palaeontologische Ergebnisse von Tiefbohrungen auf Java, nebst allgemeineren Studien ueber das Tertiaer von Java, Timor und einiger 155 Leloux \& Wesselingh. The Mart. Sammlungen des Geol. Reichs-Museums Leiden. Ser. 1, Beiträge zur Geol. Ost-Asiens und Aust. 3, 43184.

Marwick, J., 1957. Generic Revision of The Turritellidae, in: Procedings of The Malacological Society. Malacological Society, London, pp. 144-166.

Merriam, C.W., 1941. Fossil Turritellas from The Pasific Coast Region of North America. Sci. Publ. 26, 1-214.

Pandita, H., 2014. Paleontologi Moluska Neogen Famili Turritellidae di Pulau Jawa Sebagai Dasar Penyusunan Biozonasi Turritellidae. Institut Teknologi Bandung.

Pandita, H., Zaim, Y., Rizal, Y., 2013. Relationship of Biometrical Aspect of Turritellidae with Geochronological Aspect in West Java. Int. J. Geosci. 4, 777-784. https://doi.org/10.4236/ijg.2013.44071

Shuto, T., 1978. Notes on Indonesian Tertiary and Quaternary Gastropods Mainly Described by the Late Professor K. Martin II. Potamididae and Cerithiidae (Contributions to the Geology and Palaeontology of Southeast Asia, CXCIX). Geol. Palaeontol. Southeast Asia 19, 113-160.

Shuto, T., 1974. Notes on Indonesian Tertiary and Quaternary Gastropods Mainly Described by the Late Professor K. Martin I. Turritellidae and Mathildidae (Contributions to the Geology and Palaeontology of Southeast Asia, CXLIV). Geol. Palaeontol. Southeast Asia 14, 135-160. Skwarko, S.K.; Sufiati, E., 1994. Gastropoda, in: Molluscan in Indonesia Cenozoic Biostratigraphy (A Computerized Compilation),. Geol. Res. Dev. Centre, Bandung, p. 796.

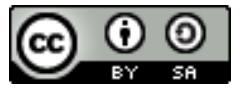

(c) 2021 Journal of Geoscience, Engineering, Environment and Technology. All rights reserved. This is an open access article distributed under the terms of the CC BY-SA License (http://creativecommons.org/licenses/by-sa/4.0/). 